\title{
FUTURE MIGRATION DECISIONS: AN EXPERIMENTAL APPROACH
}

\author{
Elina Apsite-Berina \\ University of Latvia, Latvia \\ Zaiga Krisjane \\ University of Latvia, Latvia \\ Girts Burgmanis \\ University of Latvia, Latvia
}

\begin{abstract}
The volatile political and institutional scene in Europe implies that future migrationrelated decision making can be re-assessed. Implications that migrants face might lead to a remarkable shift in migration trajectories and the need to adopt various future geographic mobility decisions. Therefore, this paper demonstrates to what extent the experimental approach can illustrate future migration-related decision making. This study explores the geographic selectivity of migration intensions of international students under four hypothetical scenarios. The data was collected in 2019 from a sample of international students in Latvia, accounting for 500 experimental participants.

The findings suggest that majority of international students studying in Latvia would prefer relocation. Besides, it is indicative that institutional barriers such as the need for a visa are much less critical than economic conditions, wage level and overall quality of life. Such indicative factors as wage level increase in Latvia would substantially boost the possibility to stay in Latvia; however, changes related to family or personal reasons are essential triggers for the students to return to their home countries.
\end{abstract}

Keywords: experimental methods, future scenarios, international students, migration decision, migration studies.

\section{Introduction}

The concept of 'migration industry' (Garapich, 2008) examines the fluid nature of migration processes, geography-specific economy, national state and people involved. Major actors channelling students to the favourable countries of education export are studied using education-migration industry nexus (LuiFarrer and Tran, 2019). Due to globalisation processes, national state policy initiatives, global marketisation (Findlay et al., 2016) of educational export, new migration stakeholder appear. Previous studies show different aspects of this process: recruiting of international students as skilled migrants (Ziguras and Law, 2006), the role of institutions for study migration (Basford and Riemsdijk, 2017), brokerage industry (Tuxen and Robertson, 2018) highlighting competition of 
'world-class universities' (Prazeres et al., 2017) for the "best and brightest" (Findlay et al., 2012) in order to improve their job prospects (Heaviside et al., 2018). Many Western countries are competing to attract a global talent pool.

As a country of emigration in the past decade, Latvia experiences an increase in immigrants' numbers; respectively, international students are choosing Latvia as their study destination country. Latvia is due to its geography - Eastern border of the EU, history - post-soviet heritage, social - number of Russian speaking minority and economic - low costs of living, low university fees and also low integration into the labour market as a drawback is an appealing choice and steps into the competition.

There are numerous studies on international student mobility worldwide covering geographies and complexities: place distinctiveness (Findlay et al., 2016), temporality (King and Raghuram, 2013), tacit skills and knowledge transfer (Baláž et al., 2004). International students are a source of culturally rich skilled labour and seen as attractive, skilled migrants providing injection into the economy at the regional and national level (Ziguras and Law, 2006), but they often are unaware of employment opportunities. Study in developed countries shows that individual support efforts from universities, businesses, public service providers and other local role-players can help international students (MorrisLange and Brands, 2015). For many international studies allow gaining better employment opportunities after graduation (Baláž et al., 2004), for some, it increases the social and cultural capital (Holloway et al., 2012) and often a drawback of part-time employment during studies (Arkoudis et al., 2019).

The methodological framework for this study is based on the migrationrelated scenario generation. This topic is also essential at the EU political (Szczepanikova \& Van Criekinge, 2018) and scientific level as several EU funded projects have been granted to explore and quantify migration scenarios. For example, project 'QuantMig' though seeing migration as an uncertain and complex problem to advance knowledge on quantifiable migration scenarios for a more transparent migration future (Boissonneault et al., 2020). Also, project 'Ymobility' by investigating young adults in the EU at different life stages and future aspirations, employed experimental methods to reveal potential destination countries' choices and responses to the future migration scenarios (Baláž and Williams, 2018). Besides (McKenzie, 2015) emphasises the need to conduct experiments to learn more about migration. He discusses policy experiments and research-designed experiments for possible patterns of population mobility.

Implications that migrants face might lead to remarkable shifts in migration trajectories and the need to adopt various plans. Therefore, this paper demonstrates to what extent the experimental approach can illustrate future migration-related decision making. This study explores hypothetical scenarios and analyses indicative aspects of possible decision-making strategies. 
The study is based on a survey experiment providing four hypothetical scenario descriptions to Latvia's international students. Hypothetical scenarios relate to the economic, institutional (Petzold and Moog, 2017) and private aspects.

Research questions explored in this study relate to the following aspects:

RQ1 What are potential migration preferences among international students in Latvia?

RQ2 What factors are the most crucial in future migration-decision?

RQ 3 To what extent external factors affect future migration decision.

\section{Literature Review}

With the rise of a knowledge based economy, demand for higher education has expanded substantially. The trend is visible in the rising number of student enrolments in higher education institutions. As a result of the massification of higher education and public policies to foster the advantages of states, the regions and cities worldwide have experienced an influx of young people from different countries looking for education opportunities (Zasina, 2020). Globalisation and internationalisation of higher education worldwide promoted the rapid growth of international students, which has approximately doubled every 20 years since 1975 (Adnett, 2010). Following countries, the United States of America, the United Kingdom, Australia, France, Germany, and the Russian Federation constitute over half of the international students studying in these six countries. The global sending countries of international students include China, India, Germany, South Korea, Nigeria, France, Saudi Arabia and several Central Asian countries (UNESCO, 2019).

It is widely agreed that many international students do not return to their home countries after completion of their degrees. It benefits the country where they graduated to increase the potential of human capital. However, the studies on the return migration of international graduates are limited, especially on migrant intention, motivation, and actual migration outcomes. Baker and Finn (2003) provides one study that does quote actual stay rates in the US, calculated from data provided by the tax authorities. He found differences in stay rates by discipline (with stay rates being highest for science and engineering students and lowest among economics and social science students) and nationality (with the highest rates among Chinese and Indian students. Other studies show that students' mental expectations or initial intentions to move predicts later mobility and remaining in the host country (Hazen \& Alberts, 2006). Yan and colleagues (2014) suggested that initial intentions to stay, as expressed in the survey, had predictive value for stay rates 1-year post-graduation. Gu and Schweisfurth (2015) took an essential step in exploring international graduate returnees' transnational identities after studying abroad. 
According to previous studies, students' migration intentions are an imperfect measure of the number of students who stay (Baker and Finn, 2003). They are a helpful indicator of future migration decisions. An experimental approach or hypothetically set conditions helps to foresee behaviour patterns of various population groups. It also advances knowledge on migration intensions and migration decision-making at the individual level.

Scholars previously have questioned how to explore an individual's responses to hypothetical future scenarios (Baláž and Williams, 2017). The scenario approach is used in previous studies concerning development potential in Latvia regions by increasing youth employability (Grinevica et al., 2016).

\section{Methodology}

The experimental research method helps to understand and, to some extent, project possible behaviour under specific experimental conditions. This can narrow the gap and provide reasonable explanations for the theoretical advancement, political recommendations, and participants' engagement in the know-how strategic planning.

The decline in local student numbers relates to two critical factors - the low fertility rate around 2000, resulting in a low youth population in Latvia today, as well as the high emigration rate, which also includes young people emigrating for study and work-related reasons. According to Apsite - Berina et al. (2020), since 2007, the number of enrolled students decreases in Latvia. However, since 2010 there is a steady increase of international students in Latvia. In 2018, India, Uzbekistan, Germany, Russia, Sweden, Ukraine, Finland, Kazakhstan, Sri Lanka and Pakistan were the countries with the most significant number of students. Students from 95 different countries worldwide are studying in Latvia (Ministry of Education and Science, 2019). The most common study directions for international students are social science and business management, followed by medicine and health care. There are different geographical trends in the choice of study paths: students from the CIS (Commonwealth of Independent States) and Georgia tend to prefer social science and business management, while European students tend to opt for medical and health care programs.

The methodological framework involved adopting the experimental method and migration scenarios from the study conducted by Balaz and Williams (Baláž and Williams, 2018) and based around hypothetical scenarios. The process of data gathering was conventional. The data was collected in the 2019 spring and autumn semester from a sample of international students in Latvia, accounting for 521 experimental participants or international students representing the foremost higher education institutions in Latvia (for example, University of Latvia, Riga Stradins University, Riga Technical University etc.) and six main geographic 
profiles: 1) member countries in the European Union before the accession of ten candidate countries on 1 May 2004 - EU 15 area (n=167), 2) new member countries in the European Union after 1 May 2004 - EU 13 countries (n=11), 3) EFTA countries $(n=13)$; 4) CIS countries $(n=105)$, 5) South Asian countries (India, Pakistan, Sri Lanka) $(\mathrm{n}=191), 6)$ other countries (Canada, the USA etc.) $(n=31)$.

The questionnaire included 40 questions, divided into thematic blocks overall student characteristics, previous schooling experiences, motivations to study abroad, the choice to study abroad, satisfaction with the current life and strategies on future carrier plans. The last thematic block included four questions on future scenarios where respondents have to show their intentions to return to their home country, stay in Latvia or move to another country if:

In this study, we analysed future migration decisions according to four hypothetical scenarios:

Scenario 1: Rapid wage level and living standard increase in Latvia in the next year.

Scenario 2: Worsening of living conditions and an increase in unemployment in the home country.

Scenario 3: Institutional restriction (residence permit, work visa) in Latvia.

Scenario 4: Unexpected shifts in family and private life.

The primary purpose of the analysis and future scenarios block was to reveal views on the decision-making process for international study move to Latvia and future intentions of current full-time international students in Latvia.

The software of IBM SPSS Statistics 26 for survey data array analysis was used in this study. Pearson chi-square test was used to determine the statistical differences among groups of international students in Latvia.

\section{Research Results}

A chi-square test of independence was performed to examine the relationship between international students' country of residence and their migration intentions if wages and living standards in Latvia increase in the next year.

The relation between the variables was significant, $X^{2}(10, N=521)=107,8$, $\mathrm{p}=0,000$. Table 1 shows that students from the EU -15 area and EFTA countries are more inclined to return to their home country regardless if wages and living standards in Latvia increase in the future. Simultaneously, students from the EU 13 countries (for example, Estonia, Lithuania, etc.), CIS and South and Middle East Asia countries are more likely to stay in Latvia if living conditions in Latvia improve. 
Apsite-Berina et al., 2021. Future Migration Decisions: an Experimental Approach

Table 1 Intentions of International Students if Wages and Living Standards for All Workers in Latvia Increase Rapidly in the Next Year (\%)

\begin{tabular}{lccc}
\hline \multirow{2}{*}{ Country of residence } & \multicolumn{3}{c}{ Intentions } \\
\cline { 2 - 4 } & $\begin{array}{c}\text { Return to home } \\
\text { country }\end{array}$ & $\begin{array}{c}\text { Stay in } \\
\text { Latvia }\end{array}$ & $\begin{array}{c}\text { Move to another } \\
\text { country }\end{array}$ \\
\hline EU - 15 area & 66,5 & 24,6 & 9,9 \\
EU - 13 countries & 45,5 & 54,5 & 0,0 \\
EFTA countries & 91,7 & 8,3 & 0,0 \\
CIS countries & 12,0 & 68,0 & 20,0 \\
South and Middle East & 29,8 & 55,1 & 15,2 \\
Asia & & & \\
Other & 27,6 & 65,5 & 6,9 \\
\hline
\end{tabular}

Source (authors' calculations based on student survey)

Table 2 Intentions of International Students if a High Rise in Unemployment and Worsening of Living Conditions Occur in a Home Country in the Next Year (\%)

\begin{tabular}{lccc}
\hline Country of residence & \multicolumn{3}{c}{ Intentions } \\
\cline { 2 - 4 } & $\begin{array}{c}\text { Return to home } \\
\text { country }\end{array}$ & $\begin{array}{c}\text { Stay in } \\
\text { Latvia }\end{array}$ & $\begin{array}{c}\text { Move to another } \\
\text { country }\end{array}$ \\
\hline EU - 15 area & 36,8 & 12,9 & 50,3 \\
EU - 13 countries & 40,0 & 20,0 & 40,0 \\
EFTA countries & 90,0 & 0,0 & 10,0 \\
CIS countries & 9,3 & 52,6 & 38,1 \\
South and Middle East & 30,5 & 36,7 & 32,8 \\
Asia & & & \\
Other & 13,8 & 34,5 & 51,7 \\
\hline
\end{tabular}

Source (authors' calculations based on student survey)

The relation between international students' country of residence and migration intentions if work and living conditions in their home country worsen (Table 2) was significant, $X^{2}(10, N=521)=79,9, p=0,000$. Students from EFTA countries are more likely to return to their home country than students from other groups. Students' form the EU countries are unlikely to stay in Latvia if work and living conditions in the home country worsen. Only students from CIS and South and Middle East Asia countries are more likely to stay in Latvia.

Evidence from scenario where various restriction for stay in Latvia are implemented show that a chi-square test of independence between variables was significant $X^{2}(10, N=521)=61,2, p=0,000$. Students from the $E U-15$ areas, EFTA and South and Middle East Asia, are more likely to return to their home country if restrictions for a stay in Latvia are implemented. Only students from CIS and EU - 13 countries are more likely than students from other groups stay 
SOCIETY. INTEGRATION. EDUCATION

Proceedings of the International Scientific Conference. Volume VI, May $28^{\text {th }}-29^{\text {th }}$, 2021. 17-27

in Latvia. However, according to this scenario, students from CIS countries are ready to move to another country.

Table 3 Intentions of International Students if Residence Permit, Work Visa, and Other Various Restrictions for a Stay in Latvia Would Be Implemented (\%)

\begin{tabular}{lccc}
\hline \multirow{2}{*}{ Country of residence } & \multicolumn{3}{c}{ Intentions } \\
\cline { 2 - 4 } & $\begin{array}{c}\text { Return to home } \\
\text { country }\end{array}$ & $\begin{array}{c}\text { Stay in } \\
\text { Latvia }\end{array}$ & $\begin{array}{c}\text { Move to another } \\
\text { country }\end{array}$ \\
\hline EU - 15 area & 65,4 & 15,4 & 19,1 \\
EU - 13 countries & 36,4 & 36,4 & 27,3 \\
EFTA countries & 83,3 & 8,3 & 8,3 \\
CIS countries & 20,2 & 37,4 & 42,4 \\
South and Middle East & 46,0 & 29,3 & 24,7 \\
Asia & & & \\
Other & 58,6 & 13,8 & 27,6 \\
\hline
\end{tabular}

Source (authors' calculations based on student survey)

Evidence from scenario where various restriction for stay in Latvia are implemented show that a chi-square test of independence between variables was significant $X^{2}(10, N=521)=61,2, p=0,000$. Students from the $E U-15$ areas, EFTA and South and Middle East Asia, are more likely to return to their home country if restrictions for a stay in Latvia are implemented. Only students from CIS and EU - 13 countries are more likely than students from other groups stay in Latvia. However, according to this scenario, students from CIS countries are ready to move to another country.

Table 4 Intentions of International Students if a Rapid Change in Family/Private Life Will Happen (\%)

\begin{tabular}{lccc}
\hline \multirow{2}{*}{ Country of residence } & \multicolumn{3}{c}{ Intentions } \\
\cline { 2 - 4 } & $\begin{array}{c}\text { Return to home } \\
\text { country }\end{array}$ & $\begin{array}{c}\text { Stay in } \\
\text { Latvia }\end{array}$ & $\begin{array}{c}\text { Move to another } \\
\text { country }\end{array}$ \\
\hline EU - 15 area & 78,8 & 11,3 & 10,0 \\
EU - 13 countries & 80,0 & 20,0 & 0,0 \\
EFTA countries & 90,9 & 0,0 & 9,1 \\
CIS countries & 48,4 & 31,6 & 20,0 \\
South and Middle East & 66,9 & 20,6 & 12,6 \\
Asia & & & 3,4 \\
Other & 72,4 & 24,1 &
\end{tabular}

Source (authors' calculations based on student survey) 
A chi-square test of independence shows that the relation between students' country of residence and migration intentions if rapid change in family/private life happen was significant, $X^{2}(10, N=521)=33,0, p=0,000$. In this scenario, students from all country groups are more likely to return to their home country. Moreover, students from CIS countries more likely than students from other groups consider staying in Latvia or moving to another country.

Students' possible intentions from CIS countries to stay in Latvia in most scenarios can be explained by features of the social milieu in Latvia, including options to work in jobs where Russian knowledge is an advantage and more democratic society than in the eastern part of the former Soviet Union. The last point partly is confirmed by the third scenario's results, revealing that students from CIS countries unlikely will move back to their home country if some restrictions are implemented in Latvia.

Students from South and Middle East Asia see Latvia as a well-recognised study destination on average in two out of four scenarios. These intentions can be explained by the attractiveness of Latvia as an EU country where students from South and Middle East Asia countries can get a university degree for a relatively low study fee, get a higher salary compared to their home country and become a part of the Asian student community of which is spreading in larger cities of Latvia.

Simultaneously, students from the EU-15 area and EFTA countries are more likely to move elsewhere because Latvia in the first place was their second choice (Apsite-Berina et al., 2020). For example, students from Germany, France, Switzerland, Norway and other Western Europe countries choose Latvia to be admitted in a desired educational programmes (mostly medicine studies), which is limited in their home countries. We assume that this explains students' intentions from the EU-15 area and EFTA countries to move back to home countries in most scenarios.

\section{Conclusions}

This paper and its innovative analytical approach enhance our understanding of international student migration intentions and under what conditions they might stay in Latvia or move to another country. For this purpose, an experimental approach was employed. In this study, we developed and tested four scenarios.

Scenario 1: rapid wage level and living standard increase in Latvia in the next year.

Scenario 2: worsening of living conditions and an increase in unemployment in the home country.

Scenario 3: institutional restriction (residence permit, work visa) in Latvia.

Scenario 4: unexpected shifts in family and private life. 
All four scenarios showed that our approach is fine-grained to address the intentions of international students and migrants in general and provide some critical starting points for modelling migrants' future decision making and behaviour.

The findings suggest that majority of international students studying in Latvia would prefer relocation. Besides, it is indicative that institutional barriers such as the need for a visa are much less critical than economic conditions, wage level and overall quality of life. Such indicative factors as wage level increase in Latvia would substantially boost the possibility to stay in Latvia; however, changes related to family or personal reasons are essential triggers for the students to return to their home countries.

Moreover, findings show that students from the EU 15 area and EFTA countries are unlikely to stay in Latvia in any of four hypothetical scenarios. Besides, even if they will not be intended to return to their home country, they most probably will move to another country. Simultaneously, students from CIS and South and Middle Asian countries are more likely to choose to stay in Latvia in the case of four proposed future scenarios. Notably, it is evident if wages and living standards in Latvia for workers increase. The intentions of students from EU 13 countries depend on the scenario. More likely, they prefer staying in Latvia if wages and living conditions increase or various restrictions are enforced. At the same time, they choose to move to their home country or another country if working and living conditions worsen or rapid changes in family/private life will happen.

This paper builds a more robust theory around multiple factors important in international student migration and offers ideas about what conditions matter most in students' decision to move or stay.

\section{Acknowledgements}

This work was supported by the ERDF grants 1.1.1.2/VIAA/1/16/184 and LZP-2020/2-0280 and National Research Program Project grant VPP-IZM2018/1-0015.

\section{References}

Adnett, N. (2010). The growth of international students and economic development: friends or foes?. Journal of Education Policy, 25(5), 625-637.

Apsite-Berina, E., Robate, L. D., Krisjane, Z., \& Burgmanis, G. (2020). The geography of international students in Latvia's higher education: prerogative or 'second chance'. In Society. Integration. Education. Proceedings of the International Scientific Conference, Vol. 6, 511-520. 
Arkoudis, S., Dollinger, M., Baik, C., \& Patience, A. (2019). International students' experience in Australian higher education: can we do better?. Higher Education, 77(5), 799-813.

Baker, J. G., \& Finn, M. G. (2003). Stay rates of foreign national doctoral students in US economics programs. Available at SSRN 398640.

Baláž, V., \& Williams, A. M. (2017). Experimental research methods in migration: From natural to true experiments. Population, Space and Place, 23(1), e1974.

Baláž, V., \& Williams, A. M. (2018). Migration decisions in the face of upheaval: An experimental approach. Population, Space and Place, 24(1), e2115.

Baláž, V., Williams, A.M. and Kollar, D. (2004). 'Temporary versus permanent youth brain drain: economic implications'. International Migration, 42(4), 3-34.

Basford, S., and Riemsdijk van M. (2017). The Role of Institutions in the Student Migrant Experiences: Norway's Quotea Scheme. Popul. Space Place 2017, 23,e2005. DOI: 10.1002/psp.2005.

Boissonneault, M., Mooyaart, J., de Jong, P., \& de Valk, H. (2020). QuantMig: The use of migration scenarios in future characterisations: A systematic review and typology. Changes, 1, 27.

Bontoux, L., Sweeney, J. A., Rosa, A. B., Bauer, A., Bengtsson, D., Bock, A. K., ... \& Watson, R. (2020). A game for all seasons: lessons and learnings from the JRC's Scenario Exploration System. World Futures Review, 12(1), 81-103.

Findlay, A., King, R. and Stam, A. (2016) Producing international student migration: an exploration of the role of marketisation in shaping international study opportunities. In: van Riemsdijk, Micheline and Wang, Qingfang (eds.) Rethinking international skilled migration. Routledge, New York (pp. 19-35). ISBN 9781138918726

Findlay, A.M., King, R., Smith, F.M., Geddes, A. and Skeldon, R. (2012). "'World class?" An investigation of globalisation, difference and international student mobility', Transactions of the Institute of British Geographers, 37(1), 118-131.

Garapich, M. P. (2008). The migration industry and civil society: Polish immigrants in the United Kingdom before and after EU enlargement. Journal of ethnic and migration studies, 34(5), 735-752.

Grinevica, L., Rivza, B., Rivza, P. (2016). Scenarios for reducing youth unemployment and promoting sustainability in the regions of Latvia. Journal of Security and Sustainabillity Issues, 5(3), 437-449. DOI: http://dx.doi.org/10.9770/jssi.2016.5.3(11)

Gu, Q., \& Schweisfurth, M. (2015). Transnational connections, competences and identities: Experiences of Chinese international students after their return' home'. British Educational Research Journal, 41(6), 947-970.

Hazen, H. D., \& Alberts, H. C. (2006). Visitors or immigrants? International students in the United States. Population, Space and Place, 12(3), 201-216.

Heaviside, J. H., Manley, J.A. \& Hudson, J. (2018). Bridging the gap between education and employment: a case study of problem-based learning implementation in Postgraduate Sport and Exercise Psychology, Higher Education Pedagogies, 3(1), 463-477, DOI: 10.1080/23752696.2018.1462095

Holloway, S. L., O'Hara, S. L., \& Pimlott-Wilson, H. (2012). Educational mobility and the gendered geography of cultural capital: The case of international student flows between Central Asia and the UK. Environment and Planning A, 44(9), 2278-2294.

King, R., \& Raghuram, P. (2013). International student migration: Mapping the field and new research agendas. Population, Space and Place, 19(2), 127-137.

Liu-Farrer, G., \& Tran, A. H. (2019). Bridging the Institutional Gaps: International Education as a Migration Industry. International Migration, 57(3), 235-249. 
McKenzie, D. (2015). Learning about migration through experiments. Migration: Economic change, social challenge, 68.

Ministry of Education and Science. (2019). Statistika par augstāko izglìtību [Latvian Higher Education Key Statistics] 2019. Riga, Latvia: Ministry of Education and Science of the Republic of Latvia. Retrieved from: http://izm.gov.lv/lv/publikacijas-unstatistika/statistika-par-izglitibu/statistika-par-augstako-izglitibu

Morris-Lange, S. and Brands, F. (2015). Train and Retain. Career Support for International Students in Canada, Germany, the Netherlands and Sweden. The Expert Council of German Foundations on Integration and Migration. Retrieved from https://www.stiftungmercator.de/media/downloads/3_Publikationen/Train_and_Retain_SVRs_Research_Uni t_Study_2015-2.pdf

Petzold, K., \& Moog, P. (2018). What shapes the intention to study abroad? An experimental approach. Higher Education, 75(1), 35-54.

Prazeres, L., Findlay, A., McCollum, D., Sander, N., Musil, E., Krisjane, Z., \& Apsite-Berina, E. (2017). Distinctive and comparative places: Alternative narratives of distinction within international student mobility. Geoforum, 80, 114-122.

Szczepanikova, A., \& Van Criekinge, T. (2018). The future of migration in the European Union.

Tuxen, N., \& Robertson, S. (2018). Brokering international education and (re) producing class in Mumbai. International Migration, 57(3), 280-294.

UNESCO. (2019). Outbound Internationally Mobile Students by Host Region. UNESCAO, Geneva. Retrieved from: http://data.uis.unesco.org/Index.aspx?queryid=172.

Yan, Z., Finn, K., Cardinal, B. J., \& Bent, L. (2014). Promoting health behaviors using peer education: A demonstration project between international and American college students. American Journal of Health Education, 45(5), 288-296.

Zasina, J. (2020). Students' leisure consumption patterns in cities: Three-dimensional pictures from Lodz and Turin. Miscellanea Geographica, 24(4), 253-262.

Ziguras, C. and Law, S-F. (2006). Recruiting international students as skilled migrants: the global 'skills race' as viewed from Australia and Malaysia, Globalisation, Societies and Education, 4(1), 59-76. DOI: 10.1080/14767720600555087. 